\section{MOLDOVA}

The armed conflict between the Romanian and Slavic populations of the Trans-Dniestria region has alarmed many Russian-speaking Jews. In the last two and a half years 32,500 Jews came to Israel from Moldova. There are 40,000 Jews still living in the region, 70 percent of whom have Israeli letters of invitation. Among them 8,000 live in the TransDniestria region, with 2,500 in Bendery and Tiraspol. One-third of the Jews who fled the armed confrontations in that region are already in Israel, while others are becoming very anxious to leave. ${ }^{9}$

Armed conflicts and the rise of Islamic fundamentalism are forcing Jews out of Central Asia, Georgia and Moldova. Simultaneously, the growing number and power of nationalist forces in Russia have repercussions in the other regions of the former Soviet Union. The open demands of these nationalist organizations for a reunification of the Russian empire makes many Jews residing in the newly formed independent states wary of the future.

\section{NOTES}

1. Shimon Chertok, "Prognozi-Vesch Netochnaya" ('Forecasts Are Not Exact'), Novoe Russkoe Slovo (September 25, 1992): 6.

2. Ben Rose, "Jewish Agency Plays Key Role in Rescuing Jews, Says Dinitz," The Canadian Jewish News (September 3, 1992): 2.

3. Shimon Chertok, "Prognozi-Vesch Netochnaya."

4. Georgii Samoilovich, "Izgnanie Naroda" ["Expulsion of a Nation"] Novoe Russkoe Slovo (June 26, 1992): 6.

5. Shimon Cherton, "Prognozi-Vesch Netochnaya."

6. Batsheva Tsur, "Airlift from Tajikistan Arrives," The Jerusalem Post International Edition (October 3, 1992).

7. Georgii Samoilovich, "Izgnanie Naroda."

8. Batsheva Tsur, "Ahkhazi Jews Set for Exodus," The Jerusalem Post International Edition (August 29, 1992): 4.

9. Shimon Cherton, "Prognozi-Vesch Netochnaya"; Allison Kaplan, "Moldavian Jews Arrive," The Jerusalem Post International Edition (August 15, 1992).

\title{
Psychosocial Changes in East German Refugees
}

\author{
Ralf Schwarzer and André Hahn
}

During the breakdown of the communist system in 1989, more than 300,000 East German citizens left their country and moved to West Germany. As part of this exodus, more than 50,000 refugees settled in West Berlin. Some came via the West German embassies in Warsaw, Prague or Budapest, while others fled under various dangerous conditions. However, many crossed the border after the fall of the Berlin Wall on November 9, 1989.

A study was launched in October 1989 (before the fall of the Berlin Wall) to examine the emotional reactions, coping strategies, social adaptation and health of these refugees in their new environment. The project was planned as a longitudinal study, with three measurement points during the first two years after their flight. The East German refugees, who were contacted individually in their temporary living quarters, were asked to take part in a psychological investigation on their new life in the West. The first stage of the study took place in the fall and winter of 1989-90, the secondstage data were obtained in the summer of 1990, and the third set was collected in the summer of 1991. A total of 1,036 refugees agreed to participate and, thus, constituted the first-stage sample. The analysis was performed on the basis of 235 refugees who had participated in all three stages. These 126 males (mean age was 31 years) and 109 females (mean age was 32 years) filled in a questionnaire measuring (among other variables) employment status, social support, anxiety, depression and health complaints.

There was a stable relationship between one's employment status and selfreported ill health, but this relationship was further elucidated when sex differences were taken into account. More extreme symptoms were reported for men than for women. Apparently, joblessness is more detrimental for men, or else ini- tial health problems inhibited job search and hiring. At all three stages, women reported more ill health than men.

A related research question was whether social support could buffer the effect of joblessness on ill health. Those refugees who were employed reported low physical symptoms, regardless of whether or not they received social support. For the refugees who were always jobless, however, social support made a considerable difference. Those who suffered from two stressors simultaneously, i.e., unemployment and lack of social support, continued to report the highest level of ill health at the three points of study. It was most interesting that those who remained jobless but received social support showed a remarkable decline in ill health over time.

This is an example of the often hypothesized buffer effect of social support within the stress and health relationship. Similar results were found for depression and anxiety (Schwarzer, Hahn and Jerusalem 1993).

\section{REFERENCE}

Schwarzer, R., A. Hahn and M. Jerusalem. 1993. "Negative Affect in East German Migrants: Longitudinal Effects of Unemployment and Social Support." Anxiety, Stress, and Coping: An International Journal 6 (in press).

Ralf Schwarzer is professor of Educational Psychology and Health Psychology at the Freie Universitat Berlin.

André Hahn is a lecturer in Health Psychology at the Freie Universitat Berlin.

(C) Authors, 1993. This open-access work is licensed under a Creative Commons Attribution-NonCommercial 4.0 International License, which permits use, reproduction and distribution in any medium for non-commercial purposes, provided the original author(s) are credited and the original publication in Refuge: Canada's Journal on Refugees is cited. 